\title{
PATTERNS OF VISUAL DEFECTS IN CHILDREN*
}

\author{
BY \\ N. L. MCNEIL \\ Barnsley, Yorks.
}

A STATISTICAL survey was carried out in November, 1953, of the records of children who attended the school ophthalmic clinic in this area. Records were available for children of pre-school age and for those attending school at the time of the analysis.

The population of this industrialized county borough has been reasonably static in the last few years; it was not disrupted during the war and there has been no great shift of population since (Table I). The population attending state schools between the statutory ages of 5 and 15 was estimated from the census figures (General Register Office, 1951).

TABLE I

\section{SCHOOL POPULATION AND NUMBERS ATTENDING CLINIC}

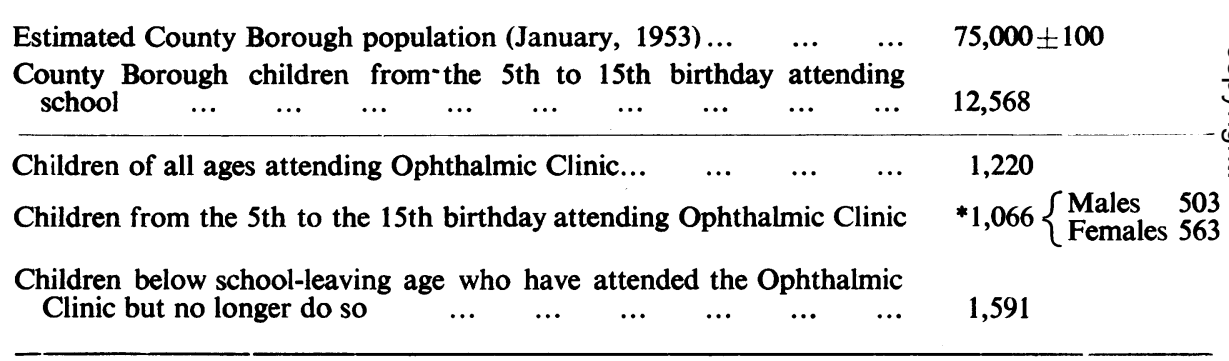

*8.5 per cent. of whole population (girls 9.27 per cent.; boys 7.74 per cent.).

\section{Material}

The majority of children of school age were referred to the clinic as a result of a medical inspection which included a visual test. It was the custom in this area to inspect on entry, i.e. between the ages of 5 and 6 years, at 8-9 years, at 11 years, and at 14 years.

Examination of the records revealed that the defects fell into two main groups:

(1) Those in children who attended once or a few times only.

(2) Those in children who had continued to attend regularly, including those seen recently who were likely to have to continue to attend.

(1) This group consisted largely of suspected squints, minor visual defects, and minor infections. It also included cases of visual defect associated with anatomical ocular defects, often of congenital or traumatic origin. These cases are briefly analysed in Table II. 
TABLE II

PATIENTS WHO NO LONGER ATTEND THE CLINIC, WITH REASON FOR ATTENDANCE AND SUBSEQUENT DISCHARGE OR NON-ATTENDANCE

\begin{tabular}{|c|c|c|c|c|}
\hline Reason for Attendance & Number & Reason for Non-Attendance & & Number \\
\hline (I) Suspected Visual Defect & 509 & $\begin{array}{l}\text { No abnormality, or negligible } \\
\text { ror only, or spectacles not nc } \\
\text { necessary } \\
\text { Refusal or default } \\
\text { Private treatment preferred } \\
\text { "Amblyopia " } \quad \ldots \quad \ldots\end{array}$ & $\begin{array}{l}\text { er- } \\
\text { ow } \\
\ldots \\
\cdots \\
\cdots\end{array}$ & $\begin{array}{r}413 \\
\\
17 \\
34 \\
45\end{array}$ \\
\hline (II) Suspected Squint & 368 & 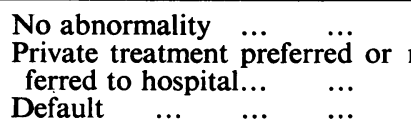 & $\begin{array}{l}\ldots \\
\ldots \\
\text { re- } \\
\cdots \\
\cdots\end{array}$ & $\begin{array}{r}283 \\
76 \\
9\end{array}$ \\
\hline (III) Infection... & 523 & 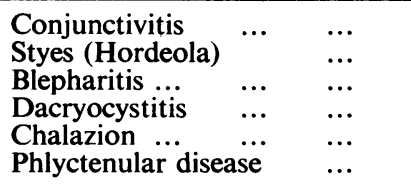 & $\begin{array}{l}\cdots \\
\cdots \\
\cdots \\
\cdots \\
\cdots\end{array}$ & $\begin{array}{r}344 \\
46 \\
57 \\
20 \\
40 \\
16\end{array}$ \\
\hline 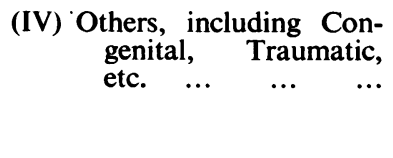 & 191 & $\begin{array}{llll}\text { Epiphora } & \ldots & \ldots & \ldots \\
\text { Injury } & \ldots & \ldots & \ldots \\
\text { Congenital } & \text { and } & & \text { developmenta } \\
\text { defects } & \ldots & \ldots & \ldots \\
\text { No abnormality } & \ldots & \ldots\end{array}$ & $\begin{array}{l}\ldots \\
\ldots \\
a \\
\cdots\end{array}$ & $\begin{array}{l}42 \\
53 \\
75 \\
21\end{array}$ \\
\hline
\end{tabular}

(2) This group was classified into patients with frank strabismus and those with more serious (non-squinting) visual defects. The latter were further classified according to the causative refractive error: hypermetropia, myopia, astigmatism, and anisometropia.

Astigmatism.-Here were included many examples of compound hypermetropic astigmatism. It was felt that should the refraction be of the order of $+2 \mathrm{D} \mathrm{sph}$. in a child aged 8 or 10 , it would be unlikely for any visual defect to be apparent unless the child also had a cylindrical error, and the astigmatism was, therefore, held to be the functional cause. On the other hand, with $+6 \mathrm{D}$ sph. and $+2 \mathrm{D}$ cyl., the error is basically hypermetropic in spite of the degree of cylindrical error.

It was decided that doubtful cases in which the cylindrical error was equal to or greater than the spherical error should be classed as astigmatic. Of the 301 cases in this category, 224 showed compound hypermetropic or hypermetropic astigmatism, 61 mixed astigmatism, and sixteen simple myopic astigmatism.

Myopia.-All cases of compound myopic astigmatism and simple spherical myopia were classed as myopic.

Anisometropia.-Here were included cases with a difference of $2 \mathrm{D}$ or more in a spherical or sphero-cylindrical error and 1.5 D or more in an astigmatic error*.

This simplified classification was adopted in order to emphasize the functional cause of the defect rather than its optical correction. The majority of surveys of this kind tend to classify the refractive errors into precise compartments which vary according to the age and locality of the sample taken, but in the present study this rigid classification was deliberately avoided, as it was thought that thereby a clearer picture of the patterns of the defects would emerge.

* These figures were arbitrarily chosen by the writer.

* All the divisions in Group 2 were analysed according to present age and age at first reporting. 


\section{Results}

It cannot be too strongly emphasized that the findings recorded below are the results not of the routine refraction of a fixed number of children but of the refraction of a series of children already found to have a definite visual defect.

GenERAL.-The true degree of morbidity is difficult to assess for the following reasons :

(a) A number of genuine cases were sent or elected to go elsewhere for treatment. This applies particularly to squints.

(b) Attendance at the clinic is not compulsory.

However, the figures recorded may be taken as representing a minimum average for the age groups concerned in this part of the country, and the patterns should not be appreciably affected by such omissions.

Table II gives an analysis of the 1,591 patients still of school age who have ceased to attend the clinic, with reasons for attendance and subsequent non-attendance.

In Sections (I) and (II)-suspected visual defect and suspected squintthe most common reasons for non-attendance were that no abnormality was found or that the error of refraction was insufficient to warrant the wearing of spectacles. Out of these two groups, 110 children elected to be treated privately or were referred to hospital. This number of genuine cases increases appreciably the proportions which are referred to later. The 45 patients classified as being amblyopic were cases of monocular amblyopia (usually associated with a missed squint or anisometropia) who in the opinion of the ophthalmologist concerned would not have benefited by wearing spectacles or any other treatment. These are discussed later.

Section (III) includes all cases of minor infection. There is no doubt that far fewer cases of this kind now come to the ophthalmologist than during the war years. It is not known whether this fall is due to a lower incidence, treatment with newer drugs, or a combination of these factors. Nine of the 57 patients (15.8 per cent.) with blepharitis required spectacles at the time or subsequently. The significance or otherwise of blepharitis as a sign of refractive error is left to the reader to judge.

Section (IV) includes all other abnormalities, whether congenital, developmental, or traumatic in origin. The largest individual group was that associated with epiphora and many of these cases responded to simple treatment. The traumata varied in severity from conjunctival foreign bodies to the after-effects of perforating injuries. The other defects included dermoids, developmental conditions of the iris, lens, and retina, optic atrophy, retinitis pigmentosa, and cases of amblyopia due to a doubtful pathological lesion.

Table III analyses all cases according to their present age; 1,066 patients were attending between their fifth and fifteenth birthdays, which is equivalent 
VISUAL DEFECTS IN CHILDREN

TABLE III

ANALYSIS ACCORDING TO PRESENT AGE OF PATIENTS

\begin{tabular}{|c|c|c|c|c|c|c|c|c|c|}
\hline \multirow{2}{*}{ Age (yrs) } & \multicolumn{3}{|c|}{ Squints } & \multicolumn{3}{|c|}{ Visual Defects } & \multicolumn{3}{|c|}{ Total } \\
\hline & Female & Male & Total & Female & Male & Total & Female & Male & Total \\
\hline $\begin{array}{r}1-2 \\
2-3 \\
3-4 \\
4-5 \\
5-6 \\
6-7 \\
7-8 \\
8-9 \\
9-10 \\
10-11 \\
11-12 \\
12-13 \\
13-14 \\
14-15 \\
15-16 \\
16-17 \\
17-18 \\
18-19\end{array}$ & $\begin{array}{r}4 \\
9 \\
13 \\
13 \\
20 \\
21 \\
23 \\
15 \\
17 \\
14 \\
10 \\
20 \\
20 \\
16 \\
8 \\
3 \\
- \\
-\end{array}$ & $\begin{array}{r}-9 \\
7 \\
16 \\
21 \\
21 \\
16 \\
12 \\
20 \\
16 \\
11 \\
20 \\
11 \\
14 \\
3 \\
1 \\
- \\
-\end{array}$ & $\begin{array}{r}4 \\
18 \\
20 \\
29 \\
41 \\
42 \\
39 \\
27 \\
37 \\
30 \\
21 \\
40 \\
31 \\
30 \\
11 \\
4 \\
- \\
-\end{array}$ & $\begin{array}{r}- \\
- \\
1 \\
3 \\
27 \\
29 \\
30 \\
48 \\
35 \\
45 \\
37 \\
59 \\
74 \\
17 \\
11 \\
5 \\
2\end{array}$ & $\begin{array}{r}- \\
- \\
1 \\
1 \\
18 \\
22 \\
29 \\
43 \\
34 \\
44 \\
37 \\
53 \\
60 \\
20 \\
9 \\
1 \\
1\end{array}$ & $\begin{array}{r}- \\
- \\
2 \\
4 \\
45 \\
51 \\
59 \\
91 \\
69 \\
89 \\
74 \\
112 \\
134 \\
37 \\
20 \\
6 \\
3\end{array}$ & $\begin{array}{r}4 \\
9 \\
13 \\
14 \\
23 \\
48 \\
52 \\
45 \\
65 \\
49 \\
55 \\
57 \\
79 \\
90 \\
25 \\
14 \\
5 \\
2\end{array}$ & $\begin{array}{r}-9 \\
7 \\
17 \\
22 \\
39 \\
38 \\
41 \\
63 \\
50 \\
55 \\
57 \\
64 \\
74 \\
23 \\
10 \\
1 \\
1\end{array}$ & $\begin{array}{r}4 \\
18 \\
20 \\
31 \\
45 \\
87 \\
90 \\
86 \\
128 \\
99 \\
110 \\
114 \\
143 \\
164 \\
48 \\
24 \\
6 \\
3\end{array}$ \\
\hline Totals & 226 & 198 & 424 & 423 & 373 & 796 & 649 & 571 & 1,220 \\
\hline
\end{tabular}

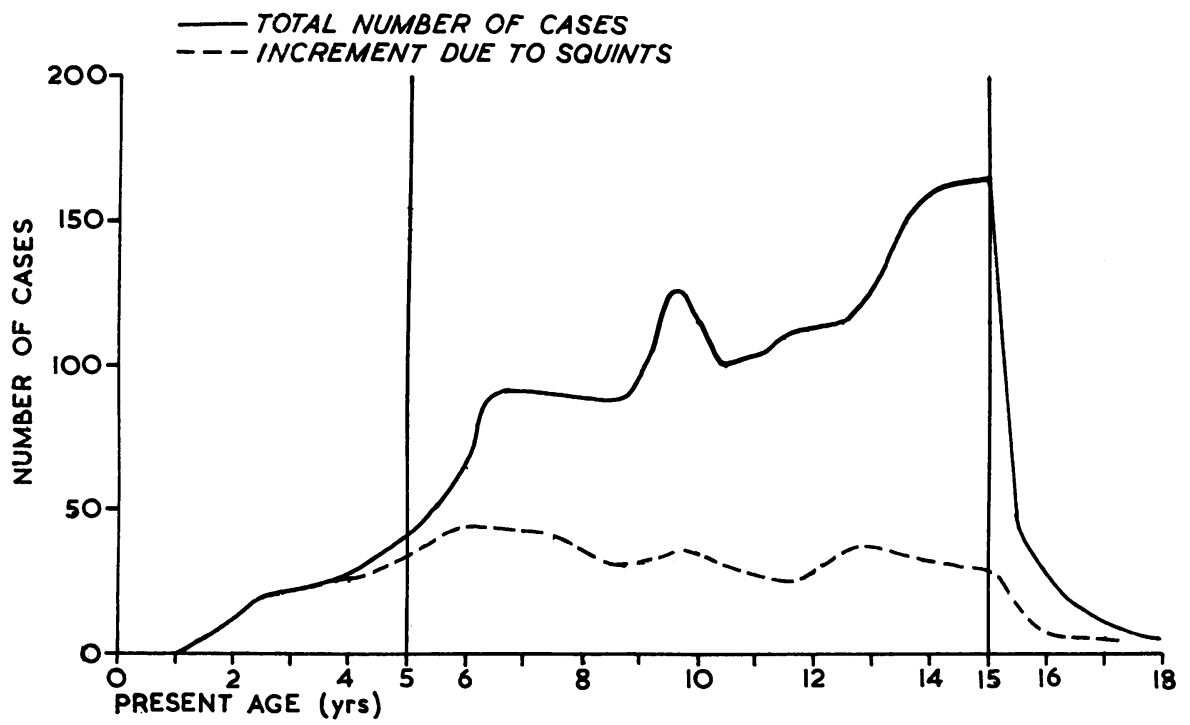

FIG. 1.-Total cases, showing increase in numbers with age, and proportion due to squints (see Table III).

to 8.5 per cent. of the corresponding population (female 9.27 per cent.; male $7 \cdot 74$ per cent.). Fig. 1 illustrates this analysis. The varying steepness of the different sections of the curve is due to variations in the components and the corresponding age-group population. The increased 
morbidity amongst girls is a consistent finding in this survey, with the exception of cases of amblyopia, which are discussed below.

TABLE IV

ANALYSIS ACCORDING TO AGE AT FIRST REPORTING

\begin{tabular}{|c|c|c|c|c|c|c|c|c|c|}
\hline \multirow{2}{*}{ Age (yrs) } & \multicolumn{3}{|c|}{ Squints } & \multicolumn{3}{|c|}{ Visual Defects } & \multicolumn{3}{|c|}{ Total } \\
\hline & Female & Male & Total & Female & Male & Total & Female & Male & Total \\
\hline $0-1$ & 9 & 2 & 11 & - & - & - & 9 & 2 & 11 \\
\hline $1-2$ & 33 & 21 & 54 & - & - & - & 33 & 21 & 54 \\
\hline $2-3$ & 43 & 42 & 85 & - & - & - & 43 & 42 & 85 \\
\hline $3-4$ & 37 & 45 & 82 & 3 & 7 & 10 & 40 & 52 & 92 \\
\hline $4-5$ & 36 & 31 & 67 & 3 & 3 & 6 & 39 & 34 & $7 \overline{3}$ \\
\hline $5-6$ & 26 & 28 & 54 & 15 & 10 & 25 & 41 & 38 & 79 \\
\hline $6-7$ & 22 & 11 & 33 & 61 & 48 & 109 & 83 & 69 & 142 \\
\hline $7-8$ & 11 & 13 & 24 & 59 & 71 & 130 & 70 & 84 & 154 \\
\hline $8-9$ & 5 & 2 & 7 & 98 & 77 & 164 & 103 & 68 & 171 \\
\hline 9-10 & 1 & 1 & 2 & 55 & 47 & 102 & 56 & 48 & 104 \\
\hline $10-11$ & 2 & 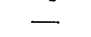 & 2 & 29 & 35 & 64 & 31 & 35 & 66 \\
\hline $11-12$ & - & 1 & 1 & 39 & 26 & 65 & 39 & 27 & 66 \\
\hline $12-13$ & - & - & - & 27 & 22 & 49 & 27 & 22 & 49 \\
\hline $13-14$ & 1 & - & 1 & 15 & 15 & 30 & 16 & 15 & 31 \\
\hline $14-15$ & - & - & - & 13 & 10 & 23 & 13 & 10 & 23 \\
\hline $15-16$ & - & 1 & 1 & 4 & 11 & 15 & 4 & 12 & 16 \\
\hline 16-17 & - & - & - & 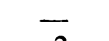 & 2 & 2 & - & 2 & 2 \\
\hline $17-18$ & - & - & - & 2 & 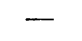 & 2 & 2 & - & 2 \\
\hline Totals & 226 & 198 & 424 & 423 & 373 & 796 & 649 & 571 & 1,220 \\
\hline
\end{tabular}

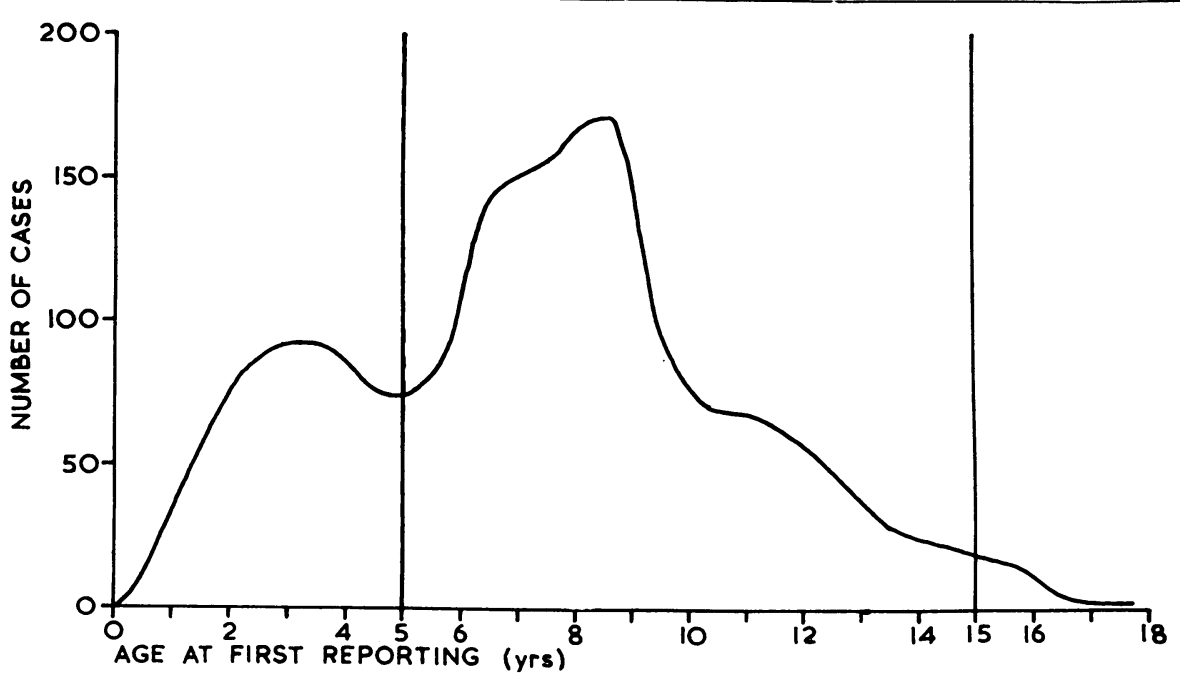

FIG. 2.-Total cases, showing age at first reporting (see Table IV).

Table IV and Fig. 2 analyse all cases according to age at first reporting at the clinic. There are two peaks: one at age 3-4 years and the other at age 9-10 years. Over 80 per cent. reported before age 10. Fig. 3 (opposite) shows the number due to squints and that due to visual defects (cf. Fig. 2). 
Table IV and Fig. 3 show that girls tend to be reported earlier than boys. Whether this is due to an earlier onset, a more obvious type of squint, or a deeper parental concern for cosmetic reasons is not known.

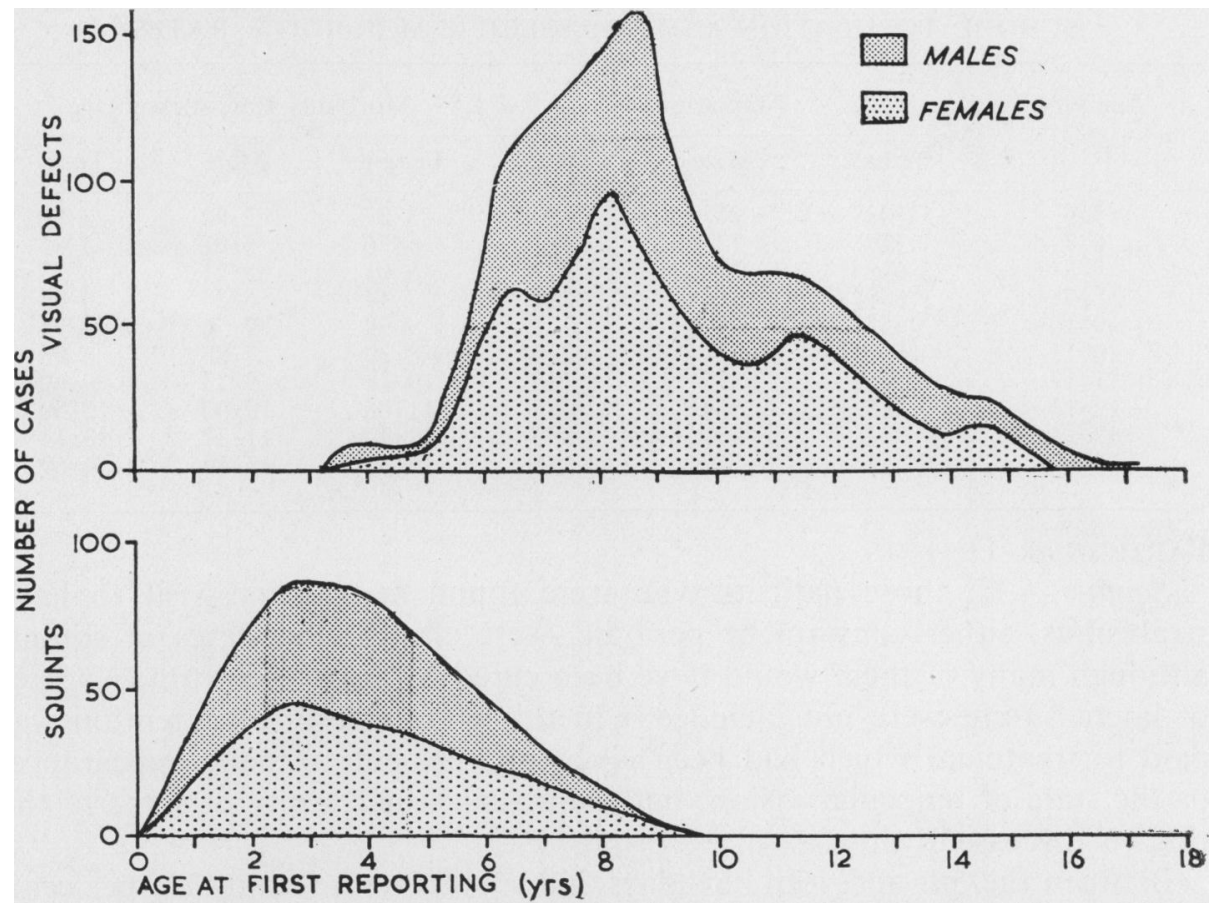

FIG. 3.-Components of Fig. 2, showing incidence of squints and other defects separately, by sex.

Table IVA summarizes the ophthalmological findings in squint cases.

TABLE IVA

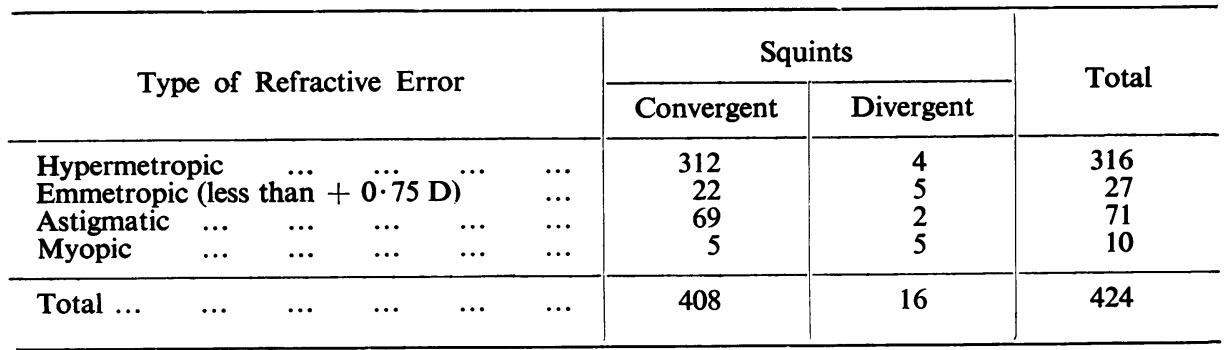

Table $\mathrm{V}$ (overleaf), giving population and age-specific morbidity rates, shows:

(1) A consistently greater female morbidity ( 10 per cent. morbidity is reached at age 11-12 in females and at age 12-13 in males).

(2) A general increase in morbidity with increase in age.

(3) The fact that the male population is consistently greater than the female.

The inconsistencies in Table $\mathrm{V}$, chiefly at age 9-10, may be due to a number of causes, the probable chief cause probably being the recent adoption 
of a policy to encourage the wearing of spectacles by children with moderate visual defects and moderate degrees of error (chiefly astigmatic).

TABLE $\mathrm{V}$

SCHOOL POPULATION AND AGE-SPECIFIC MORBIDITY RATES

\begin{tabular}{|c|c|c|c|c|c|c|}
\hline \multirow[t]{2}{*}{ Age (yrs) } & \multicolumn{3}{|c|}{ Population } & \multicolumn{3}{|c|}{ Morbidity Rate (percentage) } \\
\hline & Female & Male & Total & Female & Male & Total \\
\hline $\begin{array}{c}5-6 \\
6-7 \\
7-8 \\
8-9 \\
9-10 \\
10-11 \\
11-12 \\
12-13 \\
13-14 \\
14-15\end{array}$ & $\begin{array}{l}703 \\
710 \\
649 \\
630 \\
655 \\
590 \\
541 \\
515 \\
527 \\
551\end{array}$ & $\begin{array}{l}747 \\
777 \\
730 \\
657 \\
659 \\
634 \\
595 \\
570 \\
563 \\
565\end{array}$ & $\begin{array}{l}1,450 \\
1,487 \\
1,379 \\
1,287 \\
1,314 \\
1,224 \\
1,136 \\
1,085 \\
1,090 \\
1,116\end{array}$ & $\begin{array}{r}3 \cdot 27 \\
6 \cdot 76 \\
8 \cdot 01 \\
7 \cdot 14 \\
9 \cdot 92 \\
8 \cdot 30 \\
10 \cdot 18 \\
11 \cdot 06 \\
14 \cdot 99 \\
16 \cdot 33\end{array}$ & $\begin{array}{r}2 \cdot 94 \\
5 \cdot 02 \\
5 \cdot 21 \\
6 \cdot 24 \\
9 \cdot 56 \\
7 \cdot 88 \\
9 \cdot 23 \\
10 \cdot 00 \\
11 \cdot 37 \\
13 \cdot 10\end{array}$ & $\begin{array}{r}3 \cdot 10 \\
5 \cdot 85 \\
6 \cdot 53 \\
6 \cdot 68 \\
9 \cdot 74 \\
8 \cdot 08 \\
9 \cdot 69 \\
10 \cdot 50 \\
13 \cdot 13 \\
14 \cdot 69\end{array}$ \\
\hline
\end{tabular}

Particular Defects

Squints.-All those patients who were found at the first visit to have strabismus, either constant or periodic, were classified as cases of squint, although many of them would have been cured by the present time. Cases of latent squint were not included. In this investigation no attention was paid to treatment which had been given, the present cosmetic appearance or the state of binocular vision, but the actual visual acuity of some of the cases is discussed below.

Between the 5th and 15th birthdays 338 squints were found $(2.7$ per cent: of the corresponding population: females 2.9 per cent., males 2.4 percent.).

The incidence of convergent squint noted by various authorities varies between 0.5 and 3 per cent. and appears to depend chiefly on age. Thomson (1924) reported 3 per cent. at age 5-6 and 0.6 per cent. at age 16 , whereas Harman (1919) gave a figure of $2 \cdot 17$ per cent. The shaded area in Fig. 1 demonstrates that there appears to be constant 2-3 per cent. of the population who have or have had a squint. This is almost certainly lower than the actual percentage.

Fig. 3 shows that the peak age at which squints are reported is from 2-4 years (ranging from 1 to 8 years). The patients shown in Table IV as reporting after the age of 8 were old cases who had already been treated elsewhere. Attendance at the clinic for the first time is not necessarily related to the time of onset of the squint.

Visual Defects (Non-Squinting).-The total number of cases was 728 (5.8 per cent. of the corresponding population: females 6.4 per cent., males $5 \cdot 2$ per cent.). The largest number of new cases reported at age 8-9 (Fig. 3), at which age most of such defects were first detected. Tables VI and VII (opposite) and Figs 4-7 (overleaf) show the patterns of the different refractive errors involved. The rate amongst females is consistently higher than that in males (Table VIA, opposite) and the curves in Figs 4-7 (overleaf) all show different characteristics. 
Myopia.-The following points emerge from an examination of relevant Tables and Figures:

TABLE VI

ANALYSIS OF CASES OF VISUAL DEFECT, AT THEIR PRESENT AGE, ACCORDING TO CAUSATIVE REFRACTIVE ERROR

(Proportions expressed as percentage of all cases for the age group involved)

\begin{tabular}{|c|c|c|c|c|c|c|c|c|c|c|c|c|c|c|c|c|c|}
\hline \multirow{2}{*}{$\begin{array}{c}\text { Age } \\
\text { (yrs) }\end{array}$} & \multicolumn{4}{|c|}{ Hypermetropia } & \multicolumn{4}{|c|}{ Myopia } & \multicolumn{4}{|c|}{ Astigmatism } & \multicolumn{4}{|c|}{ Anisometropia } & \multirow{2}{*}{$\begin{array}{l}\text { Grand } \\
\text { Total }\end{array}$} \\
\hline & $\mathbf{F}$ & $\mathbf{M}$ & Total & $\begin{array}{l}\text { Per- } \\
\text { cent- } \\
\text { age }\end{array}$ & $\mathbf{F}$ & $\mathbf{M}$ & Total & $\begin{array}{c}\text { Per- } \\
\text { cent- } \\
\text { age }\end{array}$ & $\mathbf{F}$ & $\mathbf{M}$ & Total & $\begin{array}{c}\text { Per- } \\
\text { cent- } \\
\text { age }\end{array}$ & $\mathbf{F}$ & $\mathbf{M}$ & $\overline{\text { Total }}$ & $\begin{array}{l}\text { Per- } \\
\text { cent- } \\
\text { age }\end{array}$ & \\
\hline $\begin{array}{r}4-5 \\
5-6 \\
6-7 \\
7-8 \\
8-9 \\
9-10 \\
10-11 \\
11-12 \\
12-13 \\
13-14 \\
14-15 \\
15-16 \\
16-17 \\
17-18 \\
18-19\end{array}$ & $\begin{array}{r}- \\
11 \\
13 \\
7 \\
4 \\
7 \\
10 \\
6 \\
3 \\
14 \\
2 \\
1 \\
\end{array}$ & $\begin{array}{r}- \\
6 \\
4 \\
9 \\
6 \\
3 \\
10 \\
9 \\
7 \\
7 \\
2 \\
- \\
-\end{array}$ & $\begin{array}{l}- \\
17 \\
17 \\
16 \\
10 \\
10 \\
20 \\
15 \\
10 \\
21 \\
4 \\
1 \\
-\end{array}$ & $\begin{array}{r}- \\
38 \\
33 \\
27 \\
11 \\
14 \\
22 \\
20 \\
9 \\
15 \\
11 \\
5 \\
-\end{array}$ & $\begin{array}{r}- \\
2 \\
1 \\
7 \\
8 \\
6 \\
8 \\
17 \\
27 \\
29 \\
10 \\
7 \\
3 \\
2\end{array}$ & $\begin{array}{r}1 \\
1 \\
2 \\
3 \\
5 \\
9 \\
10 \\
10 \\
10 \\
23 \\
24 \\
13 \\
5 \\
1 \\
1\end{array}$ & $\begin{array}{r}1 \\
1 \\
4 \\
4 \\
12 \\
17 \\
16 \\
18 \\
27 \\
50 \\
53 \\
23 \\
12 \\
4 \\
3\end{array}$ & $\begin{array}{r}50 \\
25 \\
9 \\
8 \\
20 \\
19 \\
23 \\
20 \\
36 \\
45 \\
40 \\
62 \\
60 \\
- \\
-\end{array}$ & $\begin{array}{r}-2 \\
9 \\
10 \\
11 \\
29 \\
20 \\
24 \\
11 \\
20 \\
20 \\
3 \\
3 \\
1 \\
\end{array}$ & $\begin{array}{l}- \\
8 \\
13 \\
12 \\
16 \\
17 \\
20 \\
12 \\
18 \\
16 \\
4 \\
2 \\
-\end{array}$ & $\begin{array}{r}-2 \\
17 \\
23 \\
23 \\
45 \\
37 \\
44 \\
23 \\
38 \\
36 \\
7 \\
5 \\
1 \\
\end{array}$ & $\begin{array}{l} \\
50 \\
38 \\
45 \\
39 \\
50 \\
54 \\
50 \\
31 \\
34 \\
27 \\
19 \\
25 \\
-\end{array}$ & $\begin{array}{r}1 \\
1 \\
5 \\
5 \\
5 \\
7 \\
2 \\
3 \\
3 \\
9 \\
11 \\
2 \\
1 \\
\end{array}$ & \begin{tabular}{|r|} 
\\
2 \\
2 \\
3 \\
12 \\
4 \\
4 \\
6 \\
5 \\
13 \\
1 \\
2 \\
-
\end{tabular} & $\begin{array}{r}1 \\
1 \\
7 \\
7 \\
8 \\
19 \\
6 \\
7 \\
9 \\
14 \\
24 \\
3 \\
2 \\
1 \\
-\end{array}$ & $\begin{array}{r}50 \\
25 \\
15 \\
14 \\
14 \\
20 \\
9 \\
8 \\
12 \\
12 \\
18 \\
8 \\
10 \\
-\end{array}$ & $\begin{array}{r}2 \\
4 \\
45 \\
51 \\
59 \\
91 \\
69 \\
89 \\
74 \\
112 \\
134 \\
37 \\
20 \\
6 \\
3\end{array}$ \\
\hline Totals & 78 & 63 & 141 & - & 127 & 118 & 245 & - & 163 & 138 & 301 & - & 55 & 54 & 109 & - & 796 \\
\hline
\end{tabular}

TABLE VIA

\begin{tabular}{|c|c|c|c|c|c|c|c|}
\hline \multicolumn{4}{|c|}{ Sex } & \multirow{2}{*}{$\begin{array}{c}\text { Myopia } \\
105 \\
97\end{array}$} & \multirow{2}{*}{$\begin{array}{c}\text { Hypermetropia } \\
75 \\
61\end{array}$} & \multirow{2}{*}{$\begin{array}{c}\text { Astigmatism } \\
156 \\
132\end{array}$} & \multirow{2}{*}{ 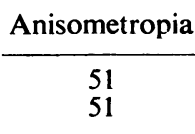 } \\
\hline $\begin{array}{l}\text { Females } \\
\text { Males }\end{array}$ & $\begin{array}{l}\ldots \\
\cdots\end{array}$ & $\begin{array}{l}\cdots \\
\cdots\end{array}$ & $\begin{array}{l}\ldots \\
\cdots\end{array}$ & & & & \\
\hline Total & $\ldots$ & $\ldots$ & $\ldots$ & 202 & 136 & 288 & 102 \\
\hline \multicolumn{3}{|c|}{ Percentage of Total } & $\ldots$ & $27 \cdot 75$ & $18 \cdot 68$ & $39 \cdot 56$ & $14 \cdot 0$ \\
\hline
\end{tabular}

TABLE VII

ANALYSIS OF CASES OF VISUAL DEFECT AT AGE OF FIRST REPORTING ACCORDING TO CAUSATIVE REFRACTIVE ERROR

(Proportions expressed as percentage of all cases for the age group involved)

\begin{tabular}{|c|c|c|c|c|c|c|c|c|c|c|c|c|c|c|c|c|c|}
\hline \multirow{2}{*}{$\begin{array}{c}\text { Age } \\
\text { (yrs) }\end{array}$} & \multicolumn{4}{|c|}{ Hypermetropia } & \multicolumn{4}{|c|}{ Myopia } & \multicolumn{4}{|c|}{ Astigmatism } & \multicolumn{4}{|c|}{ Anisometropia } & \multirow{2}{*}{$\begin{array}{l}\text { Grand } \\
\text { Total }\end{array}$} \\
\hline & $\mathbf{F}$ & $\mathbf{M}$ & Total & $\begin{array}{l}\text { Per- } \\
\text { cent- } \\
\text { age }\end{array}$ & $\mathbf{F}$ & $\mathbf{M}$ & Total & $\begin{array}{l}\text { Per- } \\
\text { cent- } \\
\text { age }\end{array}$ & $\mathbf{F}$ & $\mathbf{M}$ & Total & $\begin{array}{l}\text { Per- } \\
\text { cent- } \\
\text { age }\end{array}$ & $\mathbf{F}$ & $\mathbf{M}$ & Total & $\begin{array}{l}\text { Per- } \\
\text { cent- } \\
\text { age }\end{array}$ & \\
\hline $\begin{array}{c}3-4 \\
4-5 \\
5-6 \\
6-7 \\
7-8 \\
8-9 \\
9-10 \\
10-11 \\
11-12 \\
12-13 \\
13-14 \\
14-15 \\
15-16 \\
16-17 \\
17-18 \\
19\end{array}$ & $\begin{array}{r}-1 \\
4 \\
19 \\
14 \\
14 \\
5 \\
7 \\
5 \\
6 \\
1 \\
2 \\
- \\
-\end{array}$ & $\begin{array}{r}- \\
1 \\
16 \\
16 \\
11 \\
6 \\
2 \\
3 \\
4 \\
3 \\
1 \\
\\
-\end{array}$ & $\begin{array}{r}-1 \\
5 \\
35 \\
30 \\
25 \\
11 \\
9 \\
8 \\
10 \\
4 \\
3 \\
- \\
-\end{array}$ & $\begin{array}{l}-17 \\
20 \\
32 \\
23 \\
15 \\
11 \\
14 \\
12 \\
20 \\
13 \\
13 \\
= \\
= \\
-\end{array}$ & $\begin{array}{r}2 \\
9 \\
11 \\
19 \\
17 \\
15 \\
21 \\
14 \\
8 \\
6 \\
3 \\
\frac{2}{2}\end{array}$ & $\begin{array}{r}5 \\
1 \\
4 \\
5 \\
7 \\
12 \\
13 \\
20 \\
16 \\
12 \\
6 \\
5 \\
10 \\
2 \\
-\end{array}$ & $\begin{array}{r}7 \\
1 \\
4 \\
14 \\
18 \\
31 \\
30 \\
35 \\
37 \\
26 \\
14 \\
11 \\
13 \\
2 \\
2 \\
\end{array}$ & $\begin{array}{l}70 \\
17 \\
16 \\
13 \\
14 \\
19 \\
29 \\
55 \\
57 \\
53 \\
47 \\
48 \\
= \\
= \\
-\end{array}$ & $\begin{array}{r}1 \\
1 \\
8 \\
23 \\
28 \\
50 \\
27 \\
6 \\
7 \\
6 \\
2 \\
3 \\
1 \\
\\
-\end{array}$ & $\begin{array}{r}2 \\
2 \\
5 \\
19 \\
37 \\
30 \\
20 \\
8 \\
5 \\
5 \\
3 \\
2 \\
- \\
-\end{array}$ & $\begin{array}{r}3 \\
3 \\
13 \\
42 \\
65 \\
80 \\
47 \\
14 \\
12 \\
11 \\
5 \\
5 \\
1 \\
- \\
-\end{array}$ & $\begin{array}{l}30 \\
50 \\
52 \\
39 \\
50 \\
49 \\
46 \\
22 \\
18 \\
22 \\
17 \\
22 \\
= \\
= \\
-\end{array}$ & $\begin{array}{r}-1 \\
3 \\
10 \\
6 \\
15 \\
6 \\
1 \\
6 \\
1 \\
4 \\
2 \\
- \\
\end{array}$ & $\begin{array}{r}- \\
- \\
8 \\
11 \\
13 \\
8 \\
5 \\
2 \\
1 \\
3 \\
2 \\
1 \\
- \\
-\end{array}$ & $\begin{array}{r}-1 \\
3 \\
18 \\
17 \\
28 \\
14 \\
6 \\
8 \\
2 \\
7 \\
4 \\
1 \\
- \\
-\end{array}$ & $\begin{array}{r}\overline{17} \\
72 \\
16 \\
13 \\
17 \\
14 \\
9 \\
12 \\
4 \\
23 \\
17 \\
- \\
- \\
-\end{array}$ & $\begin{array}{r}10 \\
6 \\
25 \\
109 \\
130 \\
164 \\
102 \\
64 \\
65 \\
49 \\
30 \\
23 \\
15 \\
2 \\
2 \\
-\end{array}$ \\
\hline Totals & 78 & 63 & 141 & - & 127 & 118 & 245 & - & 163 & 138 & 301 & - & 55 & 54 & 109 & - & 796 \\
\hline
\end{tabular}



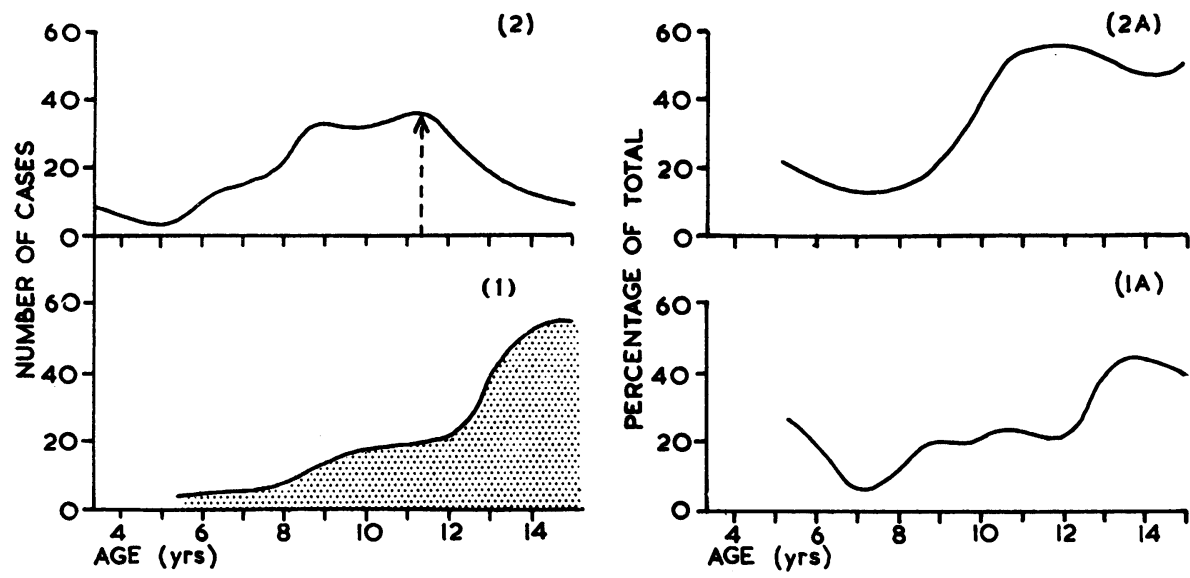

FIG. 4.- Incidence of myopia, (1) at present age, (2) age at first reporting, and (1A and 2A) percentage of total cases (see Tables VI and VII).

(2)
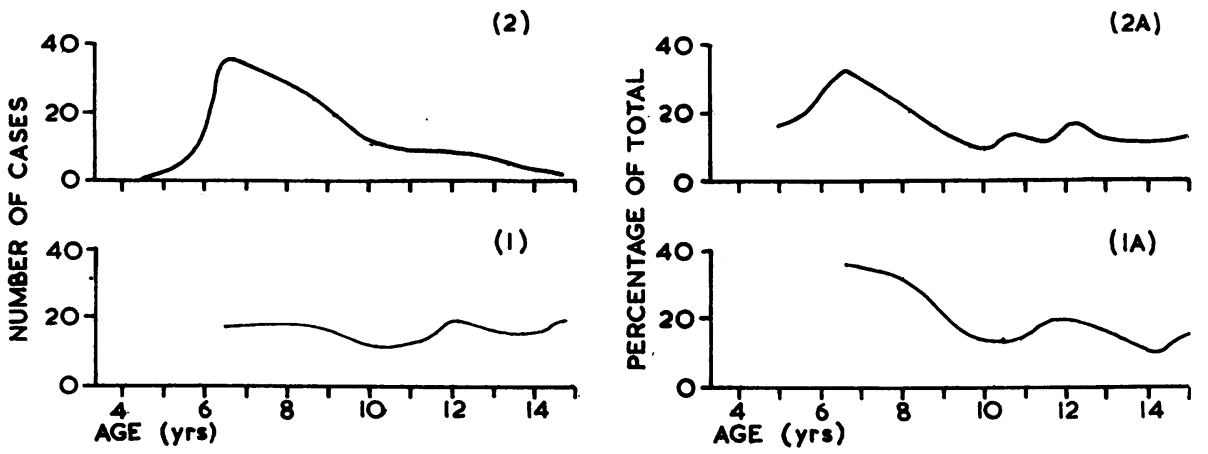

FIG. 5.-Incidence of hypermetropia, (1) at present age, (2) age at first reporting, and (1A and $2 \mathrm{~A}$ ) percentage of total cases (see Tables VI and VII).

(1) The development of these cases conforms to the accepted teaching that the majority of myopes are first observed between the ages of 5 and 15 .

The maximum incidence in this series occurs at age 11-12; Ciocco (1938) found that the peak incidence of myopic change occurred at 10-11 years. The slopes of the curves are shallow with a rather sharper fall after the age of 12 .

(2) Myopes form 19 per cent. of all new cases of visual defect at age 8-9, 55 per cent. at age 10-11, and about 50 per cent. thereafter. This means that between the ages of 10 and 15 years about half the genuine cases reported for the first time will be myopes.

(3) A few myopes are first reported in the 3rd and 4th years. In this series their number is small and no generalizations are warranted.

(4) The number of myopes increases in each successive age group. The slope is particularly steep from 11 to 13 years. This is expected from a defect which is normally progressive at this age. 

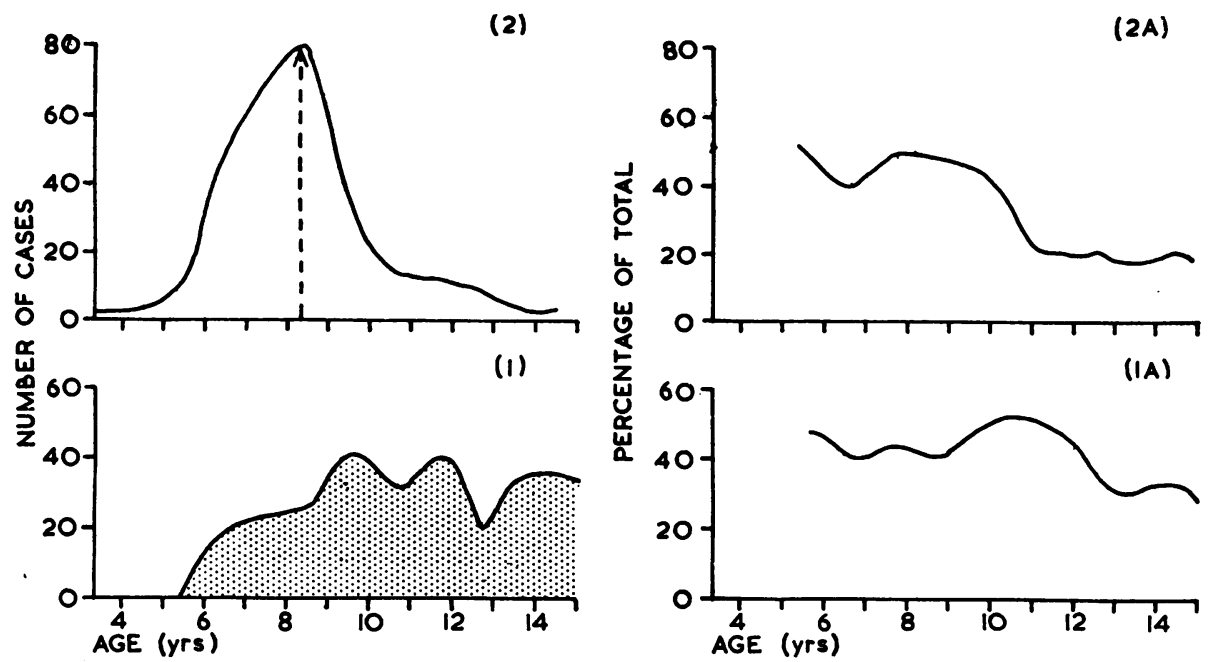

FIG. 6.-Incidence of astigmatism, (1) at present age, (2) age at first reporting, and (1A and 2A) percentage of total cases (see Tables VI and VII).
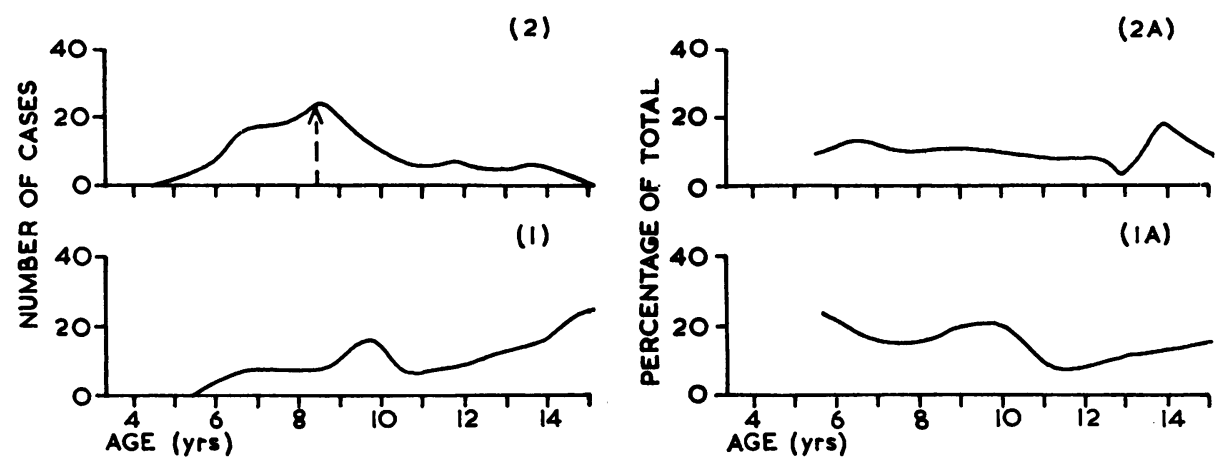

FIG. 7.- Incidence of anisometropia, (1) at present age, (2) age at first reporting, and (1A and $2 \mathrm{~A}$ ) percentage of total cases (see Tables VI and VII).

(5) Myopes comprise 20 per cent. of all cases of visual defect at age 8, and 40 per cent. from 13 to 15 years.

(6) Table $V$ shows that the proportion of myopes rises to 60 per cent. among children who wear spectacles in the age groups 15-16 and 16-17.

The school population after the age of 15 is highly selective, in that it comprises the more intelligent children; the numbers of such cases involved in this study are small.

Cohn (1883-92) quoted by Duke-Elder (1943, 1949), found 60 per cent. of myopes in those wearing glasses at the universities.

Hypermetropia.-The following points emerge:

(1) Most of these cases are reported early in their school careers (6-7 years); thereafter the numbers are low but steady and a further fall occurs at about 13 years. This suggests that hypermetropic errors cause visual defects which 
are sufficiently severe for many cases to be found early. The less severe cases tend to be reported later as the patients' accommodative efforts and requirements increase and symptoms become obvious. "Holding books close" is a not unusual symptom of the severe hypermetrope.

(2) The distribution of hypermetropes is much the same in all age groups

(3) At the earlier ages hypermetropes form a substantial proportion of all the types of refractive error other than myopia (38 per cent. at 6-7 years).

(4) The hypermetropic curves resemble the squint curves, as in Fig. 1 and that part of Fig. 3 associated with squint. As most squints are associated with hypermetropic errors, this resemblance is inevitable. There are at least twice as many squint cases (according to the definition here employed) as there are hypermetropes within the 5-15 age group. From this, it would follow that over half of the hypermetropes amongst these school children will either have a squint or give a history of having had a manifest squint at some time.

(5) As it is exceptional to prescribe spectacles for children for errors of less than $+1.5 \mathrm{D}$ sph., no such cases are included in these data.

Astigmatism.-The following points emerge:

(1) This defect is found in nearly 40 per cent. of cases of visual defect occurring in children aged from 5 to 15 years.

(2) 75 per cent. of all the astigmatic children are first reported between the ages of 6 and 10, with a well-defined peak at age 8-9, between the peak ages of reporting hypermetropia and myopia. Many of the cases are discovered at the routine inspections at age 8 , whereas the hypermetropes suffering fromo a more severe visual defect are discovered earlier, and the myopes do not develop until later. Since most cases of astigmatism do not show moresevere visual disabilities, their discovery is not prompted by an obvious inability to see.

(3) Astigmatism thus becomes the main factor in the peak reporting age of 8-9 (Figs 2 and 3).

(4) Fig. 6 shows the pattern of these cases in successive age groups. A peak occurs at about the 10th year, but some children, who are found at about age 8 to have a moderate visual defect (e.g. vision $6 / 12 \mathrm{pt}$ ), recover normal uncorrected visual acuity after wearing a moderate astigmatic correction for a year or two. If such patients have no symptoms such as headaches, they tend to dispense with their spectacles, a procedure having much to commend it.

\section{Anisometropia}

(1) Some of these patients are given glasses speculatively when the defect is first discovered if the degree of anisometropia gives any hope of recovery of useful binocular function.

(2) Cases continue to be discovered up to school-leaving age, and some of these will have some degree of unilateral amblyopia. Many children are adept at concealing a relatively small visual defect-sometimes not wilfullyand a weakness in one eye is often relegated to the subconscious, and can be discovered only by careful occlusion of the good eye in a vision test.

Amblyopia.-Table VIII (including only patients over 9 years of age) divides cases with some degree of unilateral defective vision into three groups: 
(A) Those associated with squints;

(B) Those associated with anisometropia;

(C) Those who do not now attend (the " amblyopes" of Table 11).

TABLE VIII

DETAILS OF CASES SHOWING UNILATERAL LOSS OF VISION

Group 1, best recorded (corrected) vision in affected eye is 6/9-6/18.

Group 2, best recorded vision in affected eye is $6 / 24$ or less.

\begin{tabular}{|c|c|c|c|c|c|c|c|c|c|c|c|}
\hline \multirow{3}{*}{ Group } & \multirow{3}{*}{$\begin{array}{c}\text { Age } \\
\text { (yrs) }\end{array}$} & \multirow{2}{*}{\multicolumn{3}{|c|}{ Actual Number of Squints }} & \multicolumn{6}{|c|}{ Affected Cases } & \multirow{3}{*}{$\begin{array}{l}\text { Grand } \\
\text { Totals }\end{array}$} \\
\hline & & & & & \multicolumn{2}{|c|}{ Female } & \multicolumn{2}{|c|}{ Male } & \multicolumn{2}{|c|}{ Totals } & \\
\hline & & Female & Male & Total & 1 & 2 & 1 & 2 & 1 & 2 & \\
\hline $\begin{array}{c}\text { (A) } \\
\text { Squints } \\
\text { (see Table III) }\end{array}$ & $\begin{array}{r}9-10 \\
10-11 \\
11-12 \\
12-13 \\
13-14 \\
14-15\end{array}$ & $\begin{array}{l}17 \\
14 \\
10 \\
20 \\
20 \\
16\end{array}$ & $\begin{array}{l}20 \\
16 \\
11 \\
20 \\
11 \\
14\end{array}$ & $\begin{array}{l}37 \\
30 \\
21 \\
40 \\
31 \\
30\end{array}$ & $\begin{array}{l}6 \\
4 \\
2 \\
6 \\
3 \\
3\end{array}$ & $\begin{array}{l}1 \\
2 \\
6 \\
8 \\
4\end{array}$ & $\begin{array}{l}2 \\
4 \\
2 \\
9 \\
3 \\
4\end{array}$ & $\begin{array}{l}5 \\
8 \\
3 \\
5 \\
2 \\
6\end{array}$ & $\begin{array}{r}8 \\
8 \\
4 \\
15 \\
6 \\
7\end{array}$ & $\begin{array}{r}6 \\
10 \\
3 \\
11 \\
10 \\
10\end{array}$ & $\begin{array}{r}14 \\
18 \\
7 \\
26 \\
16 \\
17\end{array}$ \\
\hline Totals & - & 97 & 92 & 189 & 24 & 21 & 24 & 29 & 48 & 50 & 98 \\
\hline $\begin{array}{c}\text { (B) } \\
\text { Anisometropes } \\
\text { (see Table V) }\end{array}$ & $\begin{array}{r}9-10 \\
10-11 \\
11-12 \\
12-13 \\
13-14 \\
14-15\end{array}$ & $\begin{array}{r}7 \\
2 \\
3 \\
3 \\
9 \\
11\end{array}$ & $\begin{array}{r}12 \\
4 \\
4 \\
6 \\
5 \\
13\end{array}$ & $\begin{array}{r}19 \\
6 \\
7 \\
9 \\
14 \\
24\end{array}$ & $\begin{array}{l}3 \\
1 \\
1 \\
2 \\
3 \\
5\end{array}$ & $\frac{1}{\frac{1}{1}}$ & $\begin{array}{l}5 \\
2 \\
3 \\
4 \\
2 \\
8\end{array}$ & $\begin{array}{l}3 \\
\frac{1}{-} \\
-\end{array}$ & $\begin{array}{r}8 \\
3 \\
4 \\
6 \\
5 \\
13\end{array}$ & $\begin{array}{l}\frac{4}{1} \\
\frac{1}{1}\end{array}$ & $\begin{array}{r}12 \\
3 \\
5 \\
7 \\
5 \\
14\end{array}$ \\
\hline Totals & - & 35 & 44 & 79 & 15 & 3 & 24 & 4 & 39 & 7 & 46 \\
\hline $\begin{array}{l}\text { (C) } \\
\text { Amblyopes- } \\
\text { No longer at- } \\
\text { tending Clinic } \\
\text { (see Table II) }\end{array}$ & $\begin{array}{r}9-10 \\
10-11 \\
11-12 \\
12-13 \\
13-14 \\
14-15\end{array}$ & $\begin{array}{l}- \\
- \\
-\end{array}$ & $\begin{array}{l}- \\
z \\
- \\
-\end{array}$ & $\begin{array}{l}- \\
E \\
- \\
-\end{array}$ & $\frac{-}{-}$ & $\begin{array}{c}-3 \\
3 \\
1 \\
2 \\
1\end{array}$ & $\begin{array}{l}1 \\
2 \\
2 \\
2 \\
2 \\
1\end{array}$ & $\begin{array}{l}1 \\
7 \\
1 \\
8 \\
3 \\
-\end{array}$ & $\begin{array}{l}1 \\
2 \\
2 \\
2 \\
6 \\
2\end{array}$ & $\begin{array}{r}1 \\
10 \\
4 \\
9 \\
5 \\
1\end{array}$ & $\begin{array}{r}2 \\
12 \\
6 \\
11 \\
11 \\
3\end{array}$ \\
\hline Totals & - & - & - & - & 5 & 10 & 10 & 20 & 15 & 30 & 45 \\
\hline
\end{tabular}

(A) More boys than girls are affected and there are more severely affected boys than girls. This may be associated with the fact that girls report earlier (Table IV), and it is also possible that such measures as occlusion are tolerated better by girls than by boys.

Groups (B) and (C) similarly show a preponderance of males in both numbers and severity. No explanation is suggested other than the possible greater tolerance to spectacles which may be shown by girls.

The 98 cases of partial amblyopia associated with squint are equivalent to 1.4 per cent. of the estimated school population in the corresponding ages. Groups (B) and (C) provide 91 cases, equivalent to 1.3 per cent. of the population. For reasons already mentioned, these figures, especially for squints, are lower than the actual totals.

Downing (1945) found a uniocular amblyopia of $6 / 12$ or over in 1,920 
cases out of 60,000 military trainees; of these, $855(1 \cdot 42$ per cent.) showed no strabismus, and 1,065 (1.77 per cent.) had an associated squint (770 convergent and 295 divergent cases). Apart from the large proportion of cases of divergent squint, there was a wide difference in age between the subjects of Downing's survey and the present study.

In Group (B), even with a liberal mathematical interpretation of anisometropia, about half the cases showed some loss of vision.

Group (C) comprised forty cases who would fit the above definition of anisometropia, three who had had a history of squint, and two others.

\section{Conclusions}

(1) The majority of new cases of visual defect, mostly cases of astigmatism, are observed at the age of 8-9 years.

(2) There is a lag in the discovery and treatment of cases of defective vision after the children have started attending school; the effects of this lag are unknown-at worst it might be a factor in the proportion of illiterates who leave school, and at best it is not to be condoned in a comprehensive health service. The teacher-hours wasted in trying to educate children of 7 or 8 years of age with only $6 / 18 \mathrm{pt}$. or $6 / 12 \mathrm{pt}$. vision may be not inconsiderable with the substantial numbers involved.

(3) The young child with substandard vision rarely shows obvious symptoms unless the defect is gross, and it is difficult to distinguish backward from visually defective children.

(4) This problem could be resolved in one of two ways:

(a) A refraction of every child early in the school year;

(b) A reliable visual test very early in the school career.

The former may be ideal but presents a formidable task. Martin (1948) advocated three refractions for every school child, the first at 7 years old, but she did not consider this practicable at present.

The large-scale use of the illiterate $\mathrm{E}$ test should enable reliable vision tests to be done in the 6th year. A short series of games or exercises in the classroom with the $\mathrm{E}$ would both reduce the time taken for a vision test and greatly increase its efficiency.

It is significant that the attitude of the Chief Medical Officer of the Ministry of Education has changed in the last few years. In 1946 and 1947 (Min. of Ed., 1949) the discovery of cases of visual disability in younger children was normally to be left to the teacher or parent, but the report for 1952 and 1953 expresses concern at the delay in discovering such cases (Min. of Ed., 1954). Purvis (1954) reported an experimental scheme in which a test was carried out on each child in its first year at school using a quick method of retinoscopy; $3 \cdot 5$ per cent. of those examined were found to have severe visual defects which had hitherto been unsuspected, and this did not include abnormalities such as squints which were already under treat- 
ment; in addition, another $5 \cdot 5$ per cent. had defects for which spectacles were considered necessary.

Tyser and Letchworth (1949) described a pilot scheme on somewhat similar lines; 8 per cent. of their cases showed defects, astigmatism being a major factor.

\section{Summary}

The visual defects found in the children of a town with a population of 75,000 are described, the cases being analysed by sex, age, and age at first reporting.

Squints and their characteristics are described, the refractive errors in the non-squinting cases are classified, and the cases showing varying degrees of amblyopia are tabulated.

A practical method of improving the school medical service by more timely observation of visual defects is suggested.

I wish to thank Dr. G. A. W. Neill, Medical Officer of Health, for permission to use the records of his department and for technical advice regarding population statistics, Mr. K. Holling, Records Clerk, for providing the school population statistics and checking the arithmetic, and Mr. E. G. Mackie for his encouragement.

\section{REFERENCES}

Clocco, A. (1938). U.S. publ. Hlth Rep., 53, 1571

CoHN, H. (1883-1892). Quoted by Duke-Elder (1943, 1949).

DogGaRT, J. H. (1950). "Diseases of Children's Eyes", 2nd ed., chap. 15. Kimpton, London.

Duke-Elder, S. (1943). "The Practice of Refraction", 4th ed., p. 81. Churchill, London. (1949). "Text-book of Ophthalmology", vol. 4, p. 4342. Kimpton, London.

General Register OfFice (1954). "Census, 1951. England and Wales County Report. Yorkshire, West Riding ". H.M.S.O., London.

HARMAN, N. Bishop (1919). Trans. ophthal. Soc. U.K., 39, 78.

Martin, P. (1948). J. med. Women's Fed., April, p. 11.

MINISTRY OF EDUCATION (1949). "The Health of the School Child", Report of the Chief Medical Officer, 1946-47. H.M.S.O., London. (1954). "The Health of the School Child ", Report of the Chief Medical Officer, 1952-53. H.M.S.O., London.

Purvis, V. P. (1954). Ibid., p. 29.

TYSER, P. A., and LetchWORTH, T. W. (1949). Brit. med. J., 2, 1022.

THOMSON, E. (1924). Trans. ophthal. Soc. U.K., 44, 238. 